\title{
Twenty-First Century Theologies of Religions : Retrospection and Future Prospects
}

\author{
Jukko, Risto
}

2017

Jukko , R 2017 , ' Twenty-First Century Theologies of Religions : Retrospection and Future

Prospects ' , Islam and Christian - Muslim Relations , vol. 28 , no. 4 , pp. 516-518 . https://doi.org/10.1080/09596410

http://hdl.handle.net/10138/297991

https://doi.org/10.1080/09596410.2017.1340007

cc_by_nc_nd

acceptedVersion

Downloaded from Helda, University of Helsinki institutional repository.

This is an electronic reprint of the original article.

This reprint may differ from the original in pagination and typographic detail.

Please cite the original version. 
Twenty-First Century Theologies of Religions: Retrospection and Future Prospects, edited by Elizabeth Harris, Paul Hedges and Shanthikumar Hettiarachchi, Leiden: Brill 2016, 396 pp., ISBN 978-90-04-32246-2.

Twenty-First Century Theologies of Religions is an anthology that turns around one central book: Alan Race's Christians and Religious Pluralism: Patterns in the Christian Theology of Religions (1983), and more specifically, around the typology exclusivism, inclusivism and pluralism, presented by Race in his seminal work. While many scholars simply take the typology for granted and repeat it, some denounce it, and others present variations on it. It is somewhat regrettable that no one of the distinguished writers of the articles mentions that the first attempt at a similar kind of typology - to my knowledge - was presented by J. Peter Schineller already in 1976 (Theological Studies 37, pp. 545-566).

The first part of the book is entitled "Disputing and Using the Typology" (Chapters 1-6). Positions are presented that both affirm and critique the typology. Comparative theology suggests that using its own tools it can bypass the tripartite typology. However, those who disagree argue that even comparative theology needs and uses a prejudgment of the type given by typology. Another position is that the theology of religions and comparative theology need to be linked to each other in a reciprocal exchange and interaction. An interesting analogy is mentioned on page 49, on which Ray Gaston quotes Michael Barnes suggesting a shift from a theology of religions to a theology of dialogue. Exclusivism witnesses to a faith which it knows through the specificity of tradition. Inclusivism witnesses to a hope to the fulfillment of all authentically religious truths and values, whereas pluralism witnesses to a love which seeks to manifest religious values (see I Corinthians 13,13). Philip Whitehead in Chapter 6, "Rethinking the Typology from a Biblical Perspective", argues that Paul's theological anthropology poses a challenge to the theology of religions, "if being in Adam entails a corruption of the intellect, (true) knowledge of God may in fact be inaccessible outside of the gospel, and so claims about God and reality bound a non-Christian religion cannot be uncritically affirmed by Christian theologians." (p. 105). The chapter is of uttermost importance as some Christian theologians of religion do not seem to take into consideration the biblical narrative.

The second part of the book is called "Pluralist Voices and Contestation" (Chapters 7-10), dealing with debates around the pluralist position in and outside of the Christian tradition. 
This part begins with a chapter (Ch. 7) written by a Jewish rabbi and professor, Tony Bayfield. The other writers (Gavin D'Costa, Paul F. Knitter and Perry Schmidt-Leukel) come from the Christian tradition and either support or criticize pluralism as a (Christian) theological position. D'Costa interestingly argues that pluralism is in fact a post-Christian position. Knitter calls the pluralist path "Pluralist Reformation", calling for a reform both for Christians and for all men and women who describe themselves as religious or spiritual. Schmidt-Leukel argues for a fundamental difference between Abrahamic faiths and the Eastern faiths, i.e., the doctrine of reincarnation.

The third part is "Beyond the Typology: New Debates, New Vistas" (Chapters 11-17). Basically it deals with such approaches that go beyond traditional discussions of the typology and its scope of its meaning. Oddbjørn Leirvik argues (Ch. 13) that an ethical, not doctrinal, approach to Islam in interreligious dialogue with Muslims would be constructive, and, quoting Hasan Askari, warns both Christians and Muslims of a monological trap that can be escaped only if they engage each other in a conversation concerning the revealed signs of God in a dialogical way. Chapter 11 by Shanthikumar Hettiarachchi and Chapter 15 by Sigrid Rettenbacher deal with the theme from the point of view of postcolonialism. Hettiarachchi gives one list of how non-Christians in South Asia have imagined Jesus, and another list of Christian theologians from the Global South giving a "de-colonized" (and contextual!) reading of Jesus: "“Jesus as the Covenant between the poor and Yahweh" (Aloysius Pieris); "Jesus as the Crucified Guru" (Thomas Thangaraj); "Jesus who is one with the Minjung (Byung Mu Ahn); "He is yang and we are yin" (Jung Young Lee); "Jesus as Mother, Woman and Shaman" (Chung Hyun Kyung); "Jesus as periphery man who pitched his tent among us" (Kosuke Koyama); "Jesus as eternal Om" (logos, S. Jesudasan)." (p. 198). It would have been interesting to read how Hettiarachchi would analyze these readings of Jesus.

Rettenbacher argues that the latest development of the (Christian) theology of religions lacks ecclesiological reflections as the necessary epistemological requirement. In addition, "there is no theory of identity or the discursive construction of identities within the theology of religions." (p. 274). This leads to an inevitable question of theological anthropology, instead of abstract entities.

The fourth part, "Some Responses to the Christian Theology of Religions" (Chapters 18-20) presents Jewish (Reuven Firestone), Muslim (Haifaa Jawad) and Buddhist (Mark Owen) reactions to the Christian theology of religions. Firestone's and Jawad's comments that 
Judaism and Islam never developed a theology of religions in the same way as Christianity, or Owen's remark that a Buddhist theology of religions would present an artificial construct, are pertinent. They reveal how the question of the theology of religions was developed by Christians, and is still largely dominated by the Christian tradition. This important dimension could have been dealt with more thoroughly in the book. Firestone's, Jawad's and Owen's comments can be compared e.g. with the (Christian) pluralist's "whole-hearted commitment to overcoming the hegemonic nature of the Christian tradition" (Marianne Moyaert, p. 244).

The pluralist position is favoured by Leonard Swidler in Foreword, when he says that simply by observing religions seems to lead humans to salvation and "provide plural paths to the ultimate human goal of 'happiness'" (p. XIII). But, of course, religions are more than empirical entities that can be observed and analysed, and their epistemological value cannot be defined simply by observing. In the Afterword Alan Race responds to debates and defends the tripartite typology. In his view, it is not thinkable that the absolutism of Christianity can ignore the salvific validity of other religions. Race is still determined to challenge religious absolutism. To conclude, this well-edited book is an excellent introduction to the present state of the theology of religions. It shows at least three important things. First, it shows how Christianity and other religions put pressure on various types of the typology, depending on their ontological and phenomenological constituencies. Secondly, it also shows how, most probably due to heritage of the Enlightenment, there is a lot of societal and cultural (Western) pressure on the Christian theology to leave exclusivism and lean more on inclusivism, and especially on pluralism. And thirdly, the book shows that the theology of religions - with interreligious dialogue and theology of dialogue - have become more urgent than ever before. However, the reader who is looking for an answer to post-typological questions will not find one single answer, but a good number of various reflections, some more convincing than others. This book is not the end of the debate.

\author{
Risto Jukko \\ Evangelical Lutheran Church of Finland \\ University of Helsinki
}

